\title{
Fatty acid and phorbol ester-mediated interference of mitogenic signaling via novel protein kinase $C$ isoforms in pancreatic $\beta$-cells (INS-1)
}

\author{
C E Wrede, L M Dickson, M K Lingohr, I Briaud and C J Rhodes \\ Pacific Northwest Research Institute and Department of Pharmacology, University of Washington, Seattle, Washington 98122, USA \\ (Requests for offprints should be addressed to C J Rhodes; Email: cjr@pnri.org)
}

\begin{abstract}
It is possible that activation of protein kinase $C$ (PKC) isoforms by free fatty acids (FFA) plays a role in the failure of pancreatic $\beta$-cell mass expansion to compensate for peripheral insulin resistance in the pathogenesis of type-2 diabetes. The effect of lipid moieties on activation of conventional (PKC- $\alpha$ and $-\beta 1)$, novel (PKC- $\delta$ ) and atypical (PKC- $\zeta)$ PKC isoforms was evaluated in an in vitro assay, using biotinylated neurogranin as a substrate. Oleoyl-Coenzyme A (CoA) and palmitoyl-CoA, but not unesterified FFA, significantly increased the activity of all PKC isoforms $(P \leq 0.05)$, particularly that for PKC- $\delta$. It was found that FFA $(0.4 \mathrm{mM}$ oleate/complexed to $0.5 \%$ bovine serum albumin) inhibited IGF-I-induced activation of protein kinase $B(P K B)$ in the pancreatic $\beta$-cell line (INS-1), but this was alleviated in the presence of the general PKC inhibitor (Gö6850; $1 \mu \mathrm{M}$ ). To further investigate whether conventional or novel PKC isoforms adversely affect $\beta$-cell proliferation, the effect of phorbol ester (phorbol 12-myristate 13-acetate; PMA)-mediated activation of these PKC isoforms on glucose/IGF-Iinduced INS-1 cell mitogenesis, and insulin receptor substrate (IRS)-mediated signal transduction was investigated. PMA-mediated activation of PKC $(100 \mathrm{nM} ; 4 \mathrm{~h})$ reduced glucose/IGF-I mediated $\beta$-cell mitogenesis ( $>50 \% ; P \leq 0.05)$, which was reversible by the general PKC inhibitor Gö6850 ( $1 \mu \mathrm{M})$, indicating an effect of PKC and not due to a non-specific PMA toxicity. PMA inhibited IGF-I-induced activation of PKB, correlating with inhibition of IGF-I-induced association of IRS-2 with the p85 regulatory subunit of phosphatidylinositol-3 kinase. However, in contrast, PMA activated the mitogen-activated protein kinases, Erk1/2. Titration inhibition analysis using PKC isoform inhibitors indicated that these PMA-induced effects were via novel PKC isoforms. Thus, FFA/PMA-induced activation of novel PKC isoforms can inhibit glucose/IGF-I-mediated $\beta$-cell mitogenesis, in part by decreasing PKB activation, despite an upregulation of Erk1/2. Thus, activation of novel PKC isoforms by long-chain acyl-CoA may well contribute to decreasing $\beta$-cell mass in the pathogenesis of type-2 diabetes, similar to their inhibition of insulin signal transduction which causes insulin resistance.
\end{abstract}

Journal of Molecular Endocrinology (2003) 30, 271-286

\section{Introduction}

The plasticity of pancreatic $\beta$-cell mass plays a key role in adapting to certain conditions such as obesity and pregnancy (Lingohr et al. 2002a, Rhodes \& White 2002). In general, increased $\beta$-cell mass and function are able to compensate for the increased insulin demand caused by peripheral insulin resistance found in obesity (Lingohr et al. 2002a). However, chronic obesity, especially if untreated, can lead to $\beta$-cell dysfunction and a failure of $\beta$-cell mass to expand in the face of insulin resistance resulting in glucose intolerance, insulin insufficiency and eventually obesity-linked type-2 diabetes (Unger \& Orci 2001, Lingohr et al. 2002a). In the USA, it has been estimated that for the year 2000 around $20 \%$ of the population was obese, and between a quarter and a third of these would progress to type-2 diabetes, raising concerns of this growing towards epidemic proportions (Mokdad et al. 2001). Similar forecasts are predicted for both Westernized and nonindustrialized countries (Fall 2001, Zimmet et al. 2001). 
There is accumulating evidence to indicate that free fatty acids (FFA), which are chronically elevated in obesity-linked type-2 diabetes, are involved in the pathogenesis of the disease (Unger \& Orci 2001, Lingohr et al. 2002a). Under normal circumstances, short-term $(<1-2 \mathrm{~h})$ exposure to exogenous FFA can have a beneficial effect to stimulate insulin secretion (Warnotte et al. 1994, Stein et al. 1996); however, chronic exposure $(>24 \mathrm{~h})$ of FFA to $\beta$-cells can adversely affect glucose-induced insulin secretion contributing to $\beta$-cell dysfunction (Bollheimer et al. 1998, McGarry \& Dobbins 1999). For peripheral insulin resistance in obesity, there is mounting evidence to suggest that increased FFA, which accompanies the accumulation of intracellular triglyceride, interferes with insulin signal transduction pathways, particularly in skeletal muscle (Kraegen et al. 2001, Moller 2001). This may be mediated by FFA itself, where it has been shown that FFA and palmitate-derived ceramide can inhibit insulin-induced activation of protein kinase $\mathrm{B}$ (PKB; also known as Akt) which leads to decreased GLUT4 translocation and reduced glucose uptake (Kellerer \& Haring 1995, De Fea \& Roth 1997, Griffin et al. 1999, Schmitz-Peiffer et al. 1999, Stratford et al. 2001). In addition, it has been shown that elevated FFA can chronically activate certain protein kinase $\mathrm{C}$ $(\mathrm{PKC}$ ) isoforms (such as $\mathrm{PKC}-\varepsilon,-\theta$ and $-\zeta$ ) to serine/threonine phosphorylate insulin receptor substrate-1 (IRS) which, in turn, dampens insulininduced IRS-mediated signaling, contributing to insulin resistance (Griffin et al. 1999, Laybutt et al. 1999, Zick 2001).

Although FFA contribute to insulin resistance, increases in pancreatic $\beta$-cell mass/function can compensate for peripheral insulin resistance, providing a possible explanation as to why $\sim 70 \%$ of obese individuals do not progress to type-2 diabetes (Unger \& Orci 2001, Lingohr et al. 2002a). Notwithstanding, it should also be noted that IRS-signal transduction pathways in pancreatic $\beta$-cells, especially when regulated by insulin-like growth factor-I (IGF-I) and glucose via IRS-2 (Hügl et al. 1998, Withers et al. 1999, Lingohr et al. 2002b), play a prominent role in maintaining $\beta$-cell mass (Withers et al. 1999, Lingohr et al. 2002a). This raises the question as to whether long-term exposure of FFA to $\beta$-cells eventually leads to interference of IRS-mediated signaling which, in turn, contributes to decreased $\beta$-cell mass associ- ated with the pathogenesis of obesity-linked type-2 diabetes (Rhodes 2000, Unger \& Orci 2001, Lingohr et al. 2002a). In this regard, it has been shown that FFA can inhibit IGF-I/glucose-induced $\beta$-cell mitogenesis in vitro (Cousin et al. 2001). In addition, FFA and palmitate-derived ceramide can cause apoptosis in islet $\beta$-cells (Shimabukuro et al. 1998, Cnop et al. 2001, Wrede et al. 2002). These observations indicate that FFA can contribute to reducing $\beta$-cell mass. It is possible that these adverse effects of FFA on $\beta$-cells are mediated, at least in part, by activation of $\mathrm{PKC}$ isoforms, similar to that contributing to insulin resistance (Zick 2001).

There are three classes of PKC isoforms, grouped as to their mode of activation (Bell \& Burns 1991, Nishizuka 1992, Liu 1996). Conventional PKG isoforms $\alpha$ and $\beta$ are allosterically activated by $\mathrm{Ca}^{2+}$, phosphatidylserine (PS) and diacylglycerol (DAG), whereas the novel isoforms PKC- $\delta,-\theta$ and $-\varepsilon$ are activated by various lipid moieties independent of $\mathrm{Ca}^{2+}$, and the atypical isoforms, such as $\mathrm{PKC}-\zeta$, are $\mathrm{Ca}^{2+}$ and DAG independent (Bell \& Burns 1991, Nishizuka 1992). In addition, the phosphatidylinositol-3-kinase (PI3-K) pathway can modulate PKC activity in several ways. First, the PI3-K product phosphatidylinositol-3,4,5-trisphosphate (PIP3) has been shown to activate $\mathrm{PKC}-\delta,-\varepsilon$ and $-\zeta$ isoforms in vitro (Toker et al. 1994). Secondly, the PIP3-activated phosphoinositide-dependent kinase-1 (PDK-1) can directly phosphorylate PKG isoforms on the activation loop in vitro (Le Good et al. 1998), rendering them active. FFA have also been shown to activate several PKG isoforms in vitro; however, it is unclear whether fatty acids (Murakami \& Routtenberg 1985, Bell \& Burns 1991, Chen \& Murakami 1992, Nishizuka 1992) or their Coenzyme A (CoA) esters (Bronfman et al. 1988, Yaney et al. 2000) activate PKG isoforms, and comparative studies regarding the activation of various $\mathrm{PKC}$ isoforms by $\mathrm{FFA}$ and relative acyl-CoA esters have not been performed. The pancreatic $\beta$-cell is known to express at least the PKG isoforms $\alpha, \beta, \delta, \varepsilon, \mu, \imath$ and $\zeta$ (Knutson \& Hoenig 1994, Yaney et al. 2002). Activation of atypical $\mathrm{PKC}-\zeta$, as well as conventional and novel $\mathrm{PKC}$ isoforms, have been indicated to partake in the stimulus-coupling mechanism for nutrientregulated insulin secretion (Tian et al. 1996). In addition, it has recently been shown that atypical 
$\mathrm{PKC}-\zeta$ contributes to increasing glucose-dependent incretin-induced $\beta$-cell mitogenesis (Buteau et al. 2001), but it is unclear whether conventional and/or novel PKC isoforms contribute to control of $\beta$-cell growth or survival. In this study, we have compared the ability of FFA, long-chain acyl-CoA as well as certain other lipid moieties to activate conventional PKC isoforms $\alpha$ and $\beta 1$, the novel conventional $\mathrm{PKC}-\delta$ and atypical $\mathrm{PKC}-\zeta$ in vitro, to address the question as to whether FFA and/or CoA-esterified FFA activate PKC isoforms. By taking advantage of the fact that phorbol esters (such as phorbol 12-myristate 13-acetate (PMA)) only activate conventional and novel PKC isoforms (Kazanietz et al. 2000), we have examined whether these particular classes of PKGs affect $\beta$-cell proliferation and glucose/IGF-I-induced IRSmediated signal transduction pathways, in the $\beta$-cell line INS-1.

\section{Materials and methods}

\section{Materials}

Total PKB, phospho-PKB $\mathrm{Thr}^{308}$ and phosphoPKB Ser ${ }^{473}$ antibodies were from New England Biolabs Inc. (Beverly, MA, USA). The SignaTECT PKC assay system, anti-phospho-extracellular regulated kinase (Erk1/2) and total-Erk1/2 antibodies were from Promega Corporation (Madison, WI, USA). Recombinant PKC- $\alpha,-\beta 1,-\delta$ and $-\zeta$ and the PKC inhibitors Gö6850 (bisindolylmaleimide I), Gö6976 and Rottlerin were obtained from Calbiochem-Novabiochem (La Jolla, GA, USA). PIP3 (1-0-stearoyl-2-0-arachidonoyl-sn-glycer-3yl-D-myo-inositol-3,4,5-trisphosphate) was from AG Scientific, Inc. (San Diego, CA, USA). DAG (1,2-dioleoyl-sn-glycerol) and PS (1- $\alpha$ phosphatidylserine) were from Avanti Polar Lipids, Inc. (Alabaster, AL, USA). PKC- $\alpha,-\beta 1,-\delta$ and $-\zeta$ antibodies were purchased from Santa Cruz Biotechnology, Inc. (Santa Cruz, CA, USA). The p70 kDa S6 protein kinase $\left(\mathrm{p} 70^{\mathrm{S} 6 \mathrm{~K}}\right)$ antiserum was a gift from Dr M G Myers (Joslin Diabetes Center, Boston, MA, USA). The anti-rabbit IgG horseradish peroxidase (HRP) conjugate was from Jackson Immuno Research (West Grove, PA, USA). IGF-I was obtained from GroPep Pty Ltd (Adelaide, Australia). PMA, oleoyl-CoA and palmitoyl-CoA were from Sigma (St Louis, MO, USA). Oleic acid $(\mathrm{OE})$ and palmitic acid (PA) were purchased from
Alltech (Deerfield, IL, USA). Recombinant inactive $\mathrm{PKB}$ and recombinant active phosphoinositidedependent kinase-1 (PDK-1) were from Upstate Biotechnology (Lake Placid, NY, USA). Protein A Sepharose CL-4B, methyl- $\left[{ }^{3} \mathrm{H}\right]$ thymidine and $\left[{ }^{32} \mathrm{P}\right] \gamma$-ATP were from Amersham Pharmacia Biotech Inc. (Piscataway, NJ, USA). The bicinchoninic (BCA) protein assay kit was from Pierce (Rockford, IL, USA) and the chemiluminescence reagent was from NEN (Boston, MA, USA). The Ready Safe scintillation fluid was from Beckman Instruments Inc. (Fullerton, CA, USA). All other chemicals were of analytical grade either from Sigma or Fisher Scientific (Pittsburgh, PA, USA).

\section{In vitro PKC assay}

The assay was adapted from the Promega SignaTECT PKC assay protocol with major changes to measure PKG activity under different conditions, using neurogranin as a PKC-specific substrate (Chakravarthy et al. 1999). PS and DAG in chloroform were dried under $\mathrm{N}_{2}$ and sonicated in $\mathrm{H}_{2} \mathrm{O}$ in order to form micelles. The final concentrations in the assay were $50 \mu \mathrm{M}$ for PS and $13 \mu \mathrm{M}$ for DAG. Forty nanograms of recombinant PKC- $\alpha$ or $100 \mathrm{ng}$ recombinant PKC- $\beta 1,-\delta$ or $-\zeta$ were incubated for $10 \mathrm{~min}$ at $30^{\circ} \mathrm{C}$ with $100 \mu \mathrm{M}$ biotinylated neurogranin as $\mathrm{PKG}$ substrate, $100 \mu \mathrm{M}$ ATP, $0.5 \mu \mathrm{Ci}\left[{ }^{32} \mathrm{P}\right] \gamma$-ATP $(3000 \mathrm{Ci} / \mathrm{mM})$ and $20 \mathrm{mM}$ Tris-Cl, $\mathrm{pH} 7 \cdot 5,2 \mathrm{mM} \mathrm{MgCl}_{2}$, $100 \mathrm{mM} \mathrm{NaCl}$ and $250 \mu \mathrm{M}$ EGTA. Depending on the experiment, $400 \mu \mathrm{M} \mathrm{CaCl}_{2}, 100 \mathrm{nM}$ PMA, $10 \mu \mathrm{M}$ PIP3, $10 \mu \mathrm{M}$ FFA or $10 \mu \mathrm{M}$ FFA-CoA were added. The reaction was stopped with $7 \cdot 5 \mathrm{M}$ guanidine hydrochloride and an equivalent of the reaction mix was spotted onto a streptavidin-coated membrane (Promega SAM ${ }^{2}$ biotin capture membrane). The membrane was washed four times in $2 \mathrm{M} \mathrm{NaCl}$ and in $2 \mathrm{M} \mathrm{NaCl} 1 \% \mathrm{H}_{3} \mathrm{PO}_{4}$, once in $\mathrm{H}_{2} \mathrm{O}$ and rinsed with 95\% ethanol. After drying, scintillation fluid was added and the samples were counted in a Beckman LS6500 scintillation counter. The data are presented as the average fold increase over $\mathrm{H}_{2} \mathrm{O} \pm$ s.E. of three to ten independent experiments.

\section{Cell culture}

The insulin-secreting, glucose-sensitive $\beta$-cell line, INS-1 (Asfari et al. 1992), was cultured in 
RPMI1640 media containing $11.2 \mathrm{mM}$ glucose, $2 \mathrm{mM}$ L-glutamine, $1 \mathrm{mM}$ sodium pyruvate, $50 \mu \mathrm{M}$ $\beta$-mercaptoethanol, $10 \%$ fetal calf serum, $100 \mathrm{U} / \mathrm{ml}$ penicillin and $100 \mu \mathrm{g} / \mathrm{ml}$ streptomycin, as previously described (Asfari et al. 1992). The cells were maintained at $37{ }^{\circ} \mathrm{C}$ with $5 \% \mathrm{CO}_{2}$ and subcultured at $70 \%$ confluence.

\section{$\left[{ }^{3} \mathrm{H}\right]$-Thymidine incorporation}

INS-1 cells were plated at a density of 15000 cells/well in 96-well plates and allowed $24 \mathrm{~h}$ to attach to the plate. After that, cells were made quiescent in starvation media (RPMI1640 media containing $0.5 \mathrm{mM}$ glucose, $0.1 \%$ bovine serum albumin (BSA), $100 \mathrm{U} / \mathrm{ml}$ penicillin and $100 \mu \mathrm{g} / \mathrm{ml}$ streptomycin) overnight. The cells were treated for $24 \mathrm{~h}$ with RPMI1640 media containing $0.5 \mathrm{mM}$, $3 \mathrm{mM}$ and $15 \mathrm{mM}$ glucose, with or without $10 \mathrm{nM}$ IGF-I. For the final $4 \mathrm{~h}$ of this incubation period, $5 \mu \mathrm{Ci} / \mathrm{ml}\left[{ }^{3} \mathrm{H}\right]$ thymidine and, in some experiments, $100 \mathrm{nM}$ PMA, were added. The cells were lysed by transferring to UniFilter-96 GF/C filter plates (Packard Instruments, Meriden, GT, USA) with the Packard filter mate cell harvester (Cambridge Technology Inc.). Packard microscint 20 scintillation fluid $(25 \mu \mathrm{l})$ was added per well and the radioactivity incorporated into DNA was determined with a Packard TopCount NXT counter, as described (Hügl et al. 1998, Cousin et al. 2001).

\section{Stimulation and cell lysis conditions}

Cells grown to $70 \%$ confluence were made quiescent in starvation media for $18 \mathrm{~h}$. All inhibitors were used at given concentrations, using stock solutions that had been prepared in dimethyl sulfoxide (DMSO) with a final DMSO concentration up to $0.5 \%$. The preincubation period was 20 min with Rottlerin and $2 \mathrm{~h}$ with Gö6850 and Gö6976. Treatment was performed with fresh starvation media containing $0.5 \mathrm{mM}, 3 \mathrm{mM}$ or $15 \mathrm{mM}$ glucose $\pm 10 \mathrm{nM}$ IGF-I with or without $100 \mathrm{nM}$ PMA for the indicated time at $37^{\circ} \mathrm{C}$. After the incubation period, the medium was completely removed and the cells were lysed in ice-cold lysis buffer containing $50 \mathrm{mM}$ HEPES (pH 7.5), 1\% NP-40, $4 \mathrm{mM}$ EDTA, $2 \mathrm{mM}$ sodium orthovanadate, $100 \mathrm{mM} \mathrm{NaF}, 10 \mathrm{mM}$ sodium pyrophosphate, $2 \mu \mathrm{M}$ leupeptin, $100 \mu \mathrm{M}$ phenylmethylsulfonyl fluoride and $1 \mu \mathrm{g} / \mathrm{ml}$ aprotinin. The lysate was sonicated, insoluble material removed by centrifugation at $16000 \boldsymbol{g}$ and the samples were stored at $-80{ }^{\circ} \mathrm{C}$.

\section{Immunoprecipitation}

Cell lysates were adjusted to $1 \mathrm{mg} / \mathrm{ml}$ total protein in lysis buffer after measuring protein concentration with the BCA protein assay kit. Samples were precleared for $1 \mathrm{~h}$ at $4{ }^{\circ} \mathrm{C}$ with $25 \mu$ l protein A Sepharose to eliminate unspecific binding. The beads were then removed, IRS-2 antibody added and the supernatant rotated overnight at $4{ }^{\circ} \mathrm{C}$. This was followed by addition of $25 \mu \mathrm{l}$ protein $\mathrm{A}$ Sepharose for $2 \mathrm{~h}$ and the lysate was washed four times with lysis buffer. Prior to gel loading, $30 \mu \mathrm{l}$ $5 \times$ SDS gel loading buffer was added and the samples were boiled for $5 \mathrm{~min}$.

\section{Protein immunoblot analysis}

Protein levels of cell lysates were determined using the BCA protein assay kit. Aliquots with $40 \mu \mathrm{g}$ protein were separated by SDS-polyacrylamide electrophoresis. After transferring to nitrocellulose, membranes were blocked in 5\% non-fat dry milk in TBST buffer (10 mM Tris-HCl, pH 8.0, $150 \mathrm{mM}$ $\mathrm{NaCl}$ and $0 \cdot 1 \%$ Tween-20) for $1 \mathrm{~h}$. The incubation with the primary antibody $(1: 1000-1: 10000)$ was performed in 5\% BSA/TBST overnight, and with the HRP-conjugated secondary antibody at 1:10 000 in 5\% BSA/TBST for $1 \mathrm{~h}$, as described (Hügl et al. 1998, Cousin et al. 2001, Dickson et al. 2001, Lingohr et al. 2002b). For detection, chemiluminescence reagent and X-ray film were used.

\section{PDK-1 assay}

Unactivated recombinant PKB (100 ng) was incubated with $5 \mathrm{ng}$ active recombinant PDK-1 for $20 \mathrm{~min}$ at $37^{\circ} \mathrm{C}$ in the presence of $50 \mu \mathrm{M}$ ATP, $250 \mu \mathrm{M}$ PS, $25 \mu \mathrm{M}$ PIP3, $50 \mu \mathrm{M}$ EGTA, $5 \mathrm{mM}$ $\mathrm{MgCl}_{2}$ and $10 \mathrm{mM}$ Hepes, $\mathrm{pH} \mathrm{7 \cdot 4.} \mathrm{Rottlerin}$ concentrations were adjusted to $1-15 \mu \mathrm{M}$. The reaction was stopped by the addition of $5 \times$ SDS gel loading buffer. Proteins were separated by SDS gel electrophoresis and PKB phosphorylation was determined by immunoblotting with phosphospecific antibodies for PKB Ser ${ }^{308}$ and PKB Ser ${ }^{473}$, as described (Dickson et al. 2001). 


\section{Statistics}

Means and s.E. were calculated using standard procedures. For significance levels, Student's $t$-test was applied, when $P<0.05$ was considered statistically significant.

\section{Results}

\section{In vitro PKC activity assay}

Various lipid moieties can differentially activate PKC isoforms (Bell \& Burns 1991, Nishizuka 1992, Liu 1996). In this study, we compared which particular lipid moieties were capable of activating, and to what extent, PKC- $\alpha$ and $-\beta 1$ (examples of conventional $\mathrm{PKG}$ isoforms), $\mathrm{PKC}-\delta$ (a model novel PKG isoform) and $\mathrm{PKC}-\zeta$ (a model atypical PKC isoform) in vitro. Since neurogranin was used as a substrate in this assay it was relatively $\mathrm{PKC}$ specific (Chakravarthy et al. 1999). Nonetheless, in initial in vitro experiments it was found that neither recombinant active PDK-1 nor immunoprecipitated activated PKB (from INS-1 cell lysates incubated at $15 \mathrm{mM}$ glucose $+10 \mathrm{nM}$ IGF-I, as previously described (Cousin et al. 2001, Dickson et al. 2001)) were able to significantly phosphorylate neurogranin (data not shown), reaffirming this assay as relatively specific for PKC activities.

The conventional PKC isoforms PKC- $\alpha$ (Fig. $1 \mathrm{~A})$ and PKC- $\beta 1$ (Fig. 1B) were best activated using a combination of PS, DAG and $\mathrm{Ca}^{2+}$. The product of PI3-K, PIP3, led to around a threefold increase for PKC- $\alpha$ and PKC- $\beta 1$ activity, independent of PS, DAG and/or $\mathrm{Ca}^{2+}$ (Fig. $1 \mathrm{~A}$ and $\mathrm{B} ; P \leq 0 \cdot 05$ ). FFA OA and PA did not increase the activity of conventional PKCs in vitro, but their CoA esters significantly increased PKC- $\alpha$ and PKC- $\beta 1$ activity by about twofold (Fig. $1 \mathrm{~A}$ and $\mathrm{B} ; P \leq 0 \cdot 05$ ).

The combination of PS and DAG, in the absence of $\mathrm{Ca}^{2+}$, led to the highest activation of the novel PKC- $\delta$, as expected (approximately eightfold; Fig. 1G). In contrast to conventional PKCs, addition of $\mathrm{Ca}^{2+}$ to PS and/or DAG reduced PKC- $\delta$ activity (Fig. 1G). PIP3 alone increased PKC- $\delta$ activity (approximately sixfold; Fig. 1C). Addition of OA-CoA and PA-CoA, but not their unesterified forms, resulted in significant activation of PKC- $\delta$ (approximately sixfold; Fig 1C).

Atypical PKC- $\zeta$ activity was modestly activated by PS and DAG, in the absence of $\mathrm{Ca}^{2+}$ (<twofold; $P<0 \cdot 05$; Fig. 1D), whereas PIP3 was the best
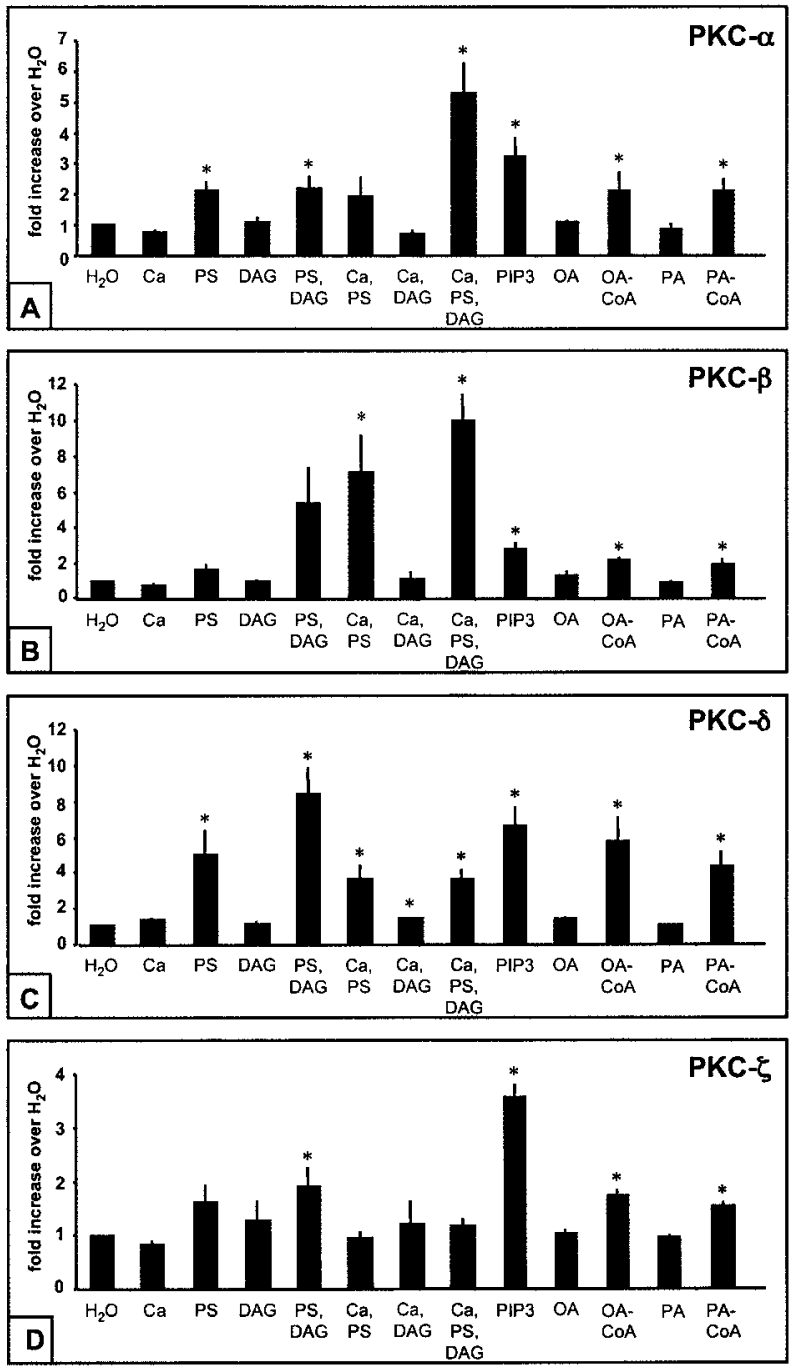

Figure $1 \mathrm{PKC}$ activity assay in vitro. PKC activity assays with $40 \mathrm{ng}$ recombinant $\mathrm{PKC}-\alpha(\mathrm{A})$ or $100 \mathrm{ng}$ recombinant PKC- $\beta 1$ (B), PKC- $\delta$ (C) or PKC- $\zeta$ (D) were incubated in the presence of known allosteric PKC activators $\left(\mathrm{Ca}^{2+}(\mathrm{Ca}), \mathrm{DAG}, \mathrm{PS}\right)$ or potential candidate PKC activators (PIP3, OA, oleoyl-CoA (OA-CoA), PA or palmitoyl-CoA (PA-CoA)) for 10 min at $30{ }^{\circ} \mathrm{C}$ with $\left.{ }^{32} \mathrm{P}\right] \gamma-\mathrm{ATP}$ and biotinylated neurogranin as substrate. Incorporated radioactivity was measured as described in Materials and methods. Data represent the mean \pm S.E. of at least three independent experiments. ${ }^{*} P \leq 0.05$ compared with $\mathrm{H}_{2} \mathrm{O}$ control.

activator of $\mathrm{PKC}-\zeta$ activity in vitro (approximately fourfold; $P \leq 0 \cdot 05$; Fig. 1D). PKC- $\zeta$ activity was also significantly $(P \leq 0.05)$ increased, albeit modestly, by OA-CoA and PA-CoA, but not by unesterified FFA (Fig. 1D). 


\section{Phospho-PKB Ser ${ }^{473}$}

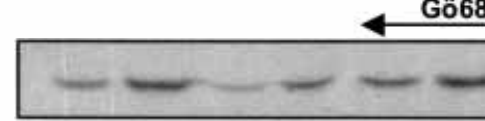

Phospho-PKB Thr ${ }^{308}$
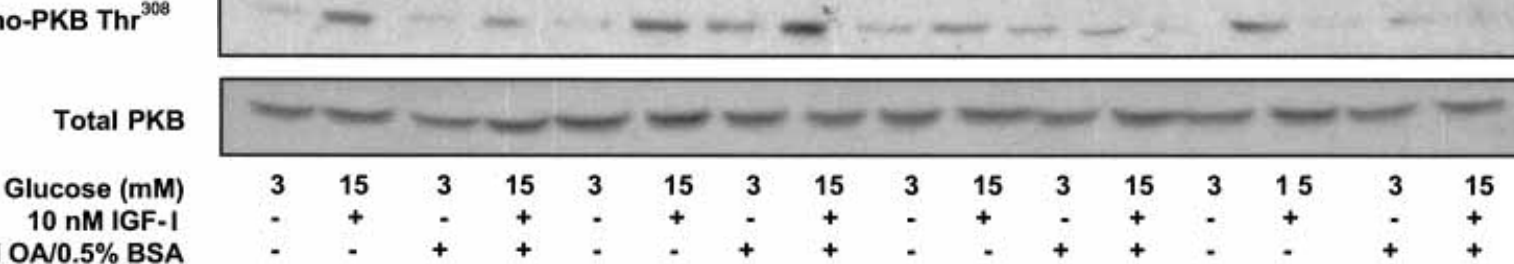

\section{$0.4 \mathrm{mM}$ OA/0.5\% BSA}

Figure 2 FFA-mediated inhibition of IGF-I-induced PKB phosphorylation activation is alleviated by the general PKC inhibitor, Gö6850. INS-1 cells were incubated at a basal $3 \mathrm{mM}$ glucose with either $0.5 \%(\mathrm{w} / \mathrm{v}) \mathrm{BSA}$ or $0.4 \mathrm{mM}$ OA complexed to $0.5 \%$ (w/v) BSA for $18 \mathrm{~h}$, as previously described (Wrede et al. 2002). Then, the cells were preincubated for $2 \mathrm{~h}$ with a general PKC inhibitor (Gö6850; $1 \mu \mathrm{M}$ ) or a conventional PKC isoform inhibitor (Gö6976; $1 \mu \mathrm{M})$ or for $20 \mathrm{~min}$ with Rottlerin $(10 \mu \mathrm{M})$, in the same media. INS-1 cells were then incubated for $10 \mathrm{~min}$ at a basal $3 \mathrm{mM}$ glucose or at stimulatory $15 \mathrm{mM}$ glucose $+10 \mathrm{nM}$ IGF-I in the continued presence of FFA and/or PKC inhibitor as indicated. Cell lysates were prepared and immunoblotted with antibodies for phospho-PKB Ser ${ }^{473}$, phospho-PKB $\mathrm{Thr}^{308}$, and total PKB, as described in Materials and methods. A representative immunoblot of at least three independent experiments is shown.

PMA $(100 \mathrm{nM})$ alone did not affect the activity of any tested PKC isoform in the in vitro assay (data not shown), in accordance with the function of phorbol esters to increase PKG membrane affinity (Mosior \& Newton 1995). Autophosphorylation of all PKC isoforms was found to be quite low and did not correlate with allosteric PKC activation (data not shown).

\section{FFA-induced inhibition of IGF-I-induced PKB activation in pancreatic $\beta$-cells (INS-1) can be averted by a general PKC inhibitor (Gö6850)}

It has been previously demonstrated that FFA can inhibit IGF-I-induced PKB activation in $\beta$-cells which may be a key to FFA-induced inhibition of $\beta$-cell mitogenesis and survival (Cousin et al. 2001, Wrede et al. 2002). An indication of PKB phosphorylation activation can be ascertained by examining the phosphorylation at $\mathrm{Thr}^{308}$ and Ser $^{473}$ of PKB by specific immunoblot analysis as previously described (Dickson et al. 2001, Wrede et al. 2002). INS-1 cells were incubated at a basal $3 \mathrm{mM}$ glucose with either $0.5 \%(\mathrm{w} / \mathrm{v})$ BSA or $0.4 \mathrm{mM}$ OA complexed to $0.5 \%$ (w/v) BSA for $18 \mathrm{~h}$, as previously described (Wrede et al. 2002). Then, the cells were preincubated for $2 \mathrm{~h}$ with a general PKC inhibitor (Gö6850; $1 \mu \mathrm{M}$ ) (Toullec et al. 1991) or a conventional PKC isoform inhibitor (Gö6976; $1 \mu \mathrm{M}$ ) (Martiny-Baron et al. 1993), or for $20 \mathrm{~min}$ with Rottlerin $(10 \mu \mathrm{M})$, a relatively specific inhibitor of PKC- $\delta$ (Gschwendt et al. 1994), in the same media. INS-1 cells were then incubated for $10 \mathrm{~min}$ at $37^{\circ} \mathrm{C}$ at a basal $3 \mathrm{mM}$ glucose or at stimulatory $15 \mathrm{mM}$ glucose $+10 \mathrm{nM}$ IGF-I in the continued presence of FFA and/or PKC inhibitor as indicated (Fig. 2). In the presence of $0.4 \mathrm{mM} \mathrm{OA} /$ $0.5 \% \mathrm{BSA}$, but in the absence of PKC inhibitors, an FFA-mediated inhibition of IGF-I-induced PKB $\mathrm{Thr}^{308}$ and $\mathrm{Ser}^{473}$ phosphorylation activation was observed (Fig. 2), as previously demonstrated (Wrede et al. 2002). However, in the presence of the general PKC inhibitor (Gö6850), this FFAmediated inhibition of IGF-I-induced PKB activation was alleviated (Fig. 2). In contrast, the conventional PKG isoform inhibitor (Gö6976) was unable to prevent FFA-mediated inhibition of PKB activation (Fig. 2). In the absence of FFA, Rottlerin appeared to have a general effect on inhibiting IGF-I-induced PKB $\mathrm{Thr}^{308}$ phosphorylation but not IGF-I-induced PKB Ser ${ }^{473}$ phosphorylation (Fig. 2), perhaps consistent with Rottlerin also being able to inhibit PDK-1 (Davies et al. 2000) which, in turn, would reduce PDK-1-mediated PKB Thr ${ }^{308}$ phosphorylation (Dickson et al. 2001). Nonetheless, Rottlerin was unable to alleviate the FFA-mediated inhibition of IGF-I-induced PKB Thr ${ }^{308}$ or Ser ${ }^{473}$ phosphorylation (Fig. 2). These data suggest the possibility that FFA-mediated inhibition of PKB activation in pancreatic $\beta$-cells (INS-1) may, at least in part, be mediated by FFA-induced activation of a novel or atypical PKC isoform. 


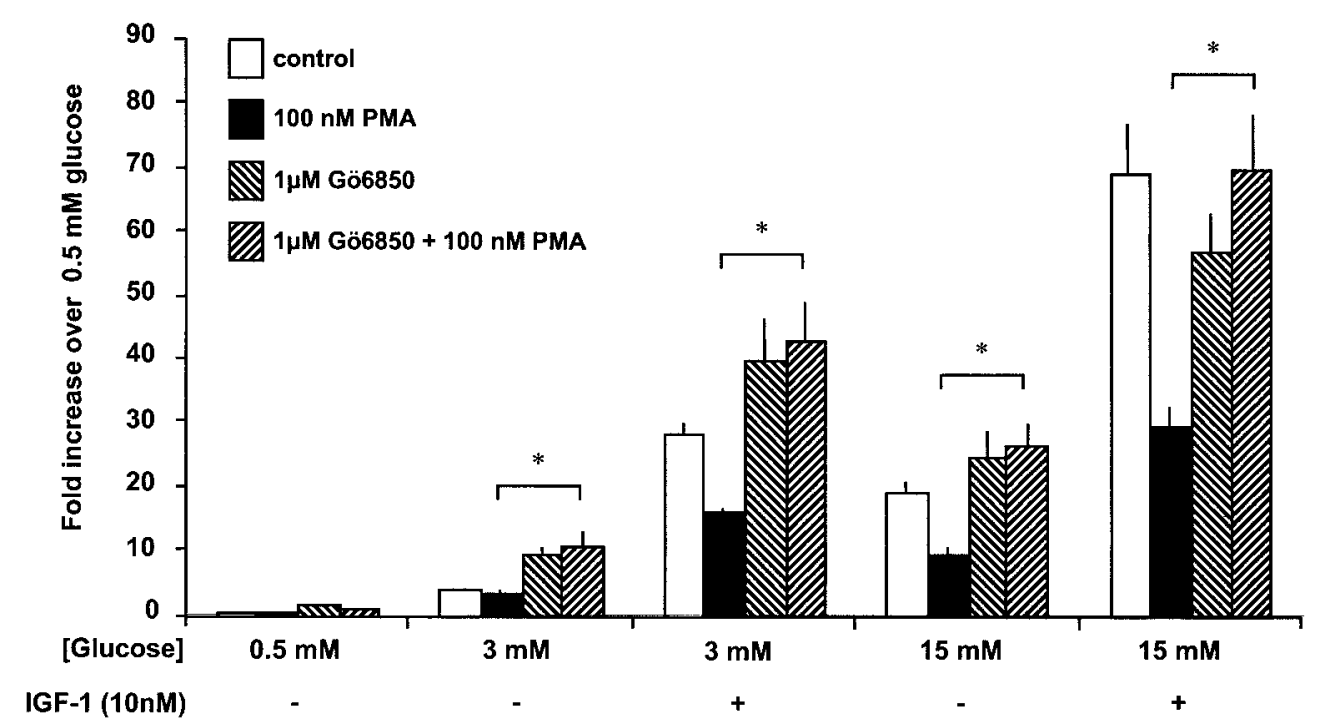

Figure $3\left[{ }^{3} \mathrm{H}\right]$ Thymidine incorporation assays in INS-1 cells with the PKC activator PMA. INS-1 cells were cultured in 96-well plates for $24 \mathrm{~h}$ and made quiescent by incubating for $18 \mathrm{~h}$ in starvation media $(0.5 \mathrm{mM}$ glucose) overnight. The cells were subsequently cultured for $24 \mathrm{~h}$ in RPMI1640 medium containing the indicated glucose concentrations with or without $10 \mathrm{nM}$ IGF-I. In the last $4 \mathrm{~h},\left[{ }^{3} \mathrm{H}\right]$ thymidine or $\left[{ }^{3} \mathrm{H}\right]$ thymidine with PMA (100 nM) was added $\pm 1 \mu \mathrm{M}$ Gö6850 (the bisindolylmaleimide general PKC inhibitor) as indicated. The data represent at least five independent experiments done in triplicate. Means \pm S.E. are shown. ${ }^{*} P \leq 0.001$ between the indicated groups.

\section{Short-term PMA treatment decreased pancreatic $\beta$-cell (INS-1) mitogenesis, via activation of PKC}

It has recently been indicated that the atypical $\mathrm{PKC}$ isoform, $\mathrm{PKC}-\zeta$, plays a positive role in glucagon-like peptide-1-induced $\beta$-cell proliferation and is unlikely to have any negative effect on mitogenesis (Buteau et al. 2001). In order to examine the role that conventional and novel PKC isoforms might play in the control of $\beta$-cell proliferation, we took advantage of the characteristic that phorbol esters (such as PMA) preferentially activate conventional and novel PKG isoforms, with little effect on activating atypical PKG isoforms (Liu 1996, Kazanietz et al. 2000). However, it should be noted that long-term exposure of high concentrations of PMA $(>1 \mu \mathrm{M})$ to pancreatic $\beta$-cells reduces the expression of several PKC isoforms (Yaney et al. 2000, 2002), and thus these series of experiments were restricted to a relatively short-term 4-h incubation with PMA. In preliminary dose-response experiments, it was found that a maximal effect of PMA to inhibit glucose/IGF-I-induced $\beta$-cell mitogenesis in $4 \mathrm{~h}$ (see below; Fig. 3) occurred between 50 and100 nM PMA although significant inhibition was also observed at $\geq 5 \mathrm{nM}$ PMA (data not shown). A stimulatory glucose concentration $(15 \mathrm{mM})$ promoted $\left[{ }^{3} \mathrm{H}\right]$ thymidine incorporation in INS-1 cells above that at basal $3 \mathrm{mM}$ glucose $(P \leq 0 \cdot 01$; Fig. 3$)$, as previously shown (Hügl et al. 1998). IGF-I (10 $\mathrm{nM})$ further increased INS-1 cell proliferation at both basal $3 \mathrm{mM}$ glucose and stimulatory $15 \mathrm{mM}$ glucose $(P \leq 0 \cdot 01$; Fig. 3). PMA (100 nM) had no effect on INS-1 cell mitogenesis at basal $3 \mathrm{mM}$ glucose. However, PMA caused a significant $\sim 50 \%$ reduction in $\left[{ }^{3} \mathrm{H}\right]$ thymidine incorporation at stimulatory $15 \mathrm{mM}$ glucose $(P \leq 0 \cdot 01$; Fig. 3). PMA also significantly inhibited IGF-I-induced INS-1 cell mitogenesis at both $3 \mathrm{mM}$ and $15 \mathrm{mM}$ glucose, also by about $50 \%(P \leq 0 \cdot 005$; Fig. 3$)$. The presence of bisindolylmaleimide Gö6850 (1 $\mu \mathrm{M})$, a general PKG inhibitor (Toullec et al. 1991), during the $\left[{ }^{3} \mathrm{H}\right]$ thymidine incorporation assay completely prevented the inhibitory effect of PMA on INS-1 cell proliferation at $15 \mathrm{mM}$ glucose and in the presence of IGF-I at both $3 \mathrm{mM}$ or $15 \mathrm{mM}$ glucose (Fig. 3). This reaffirmed that the PMA effect was 
not due to non-specific cytotoxicity. In contrast, the conventional PKG isoform inhibitor (Gö6976; $1 \mu \mathrm{M})$ or Rottlerin did not appear to significantly alleviate PMA-induced inhibition of glucose/IGFI-induced INS-1 cell proliferation (data not shown).

\section{Phorbol ester inhibited PKB phosphorylation and $\mathrm{p} 85 \mathrm{kDa}$ regulatory subunit of PI3-K (p85)/IRS-2 association, but increased Erk1/2 phosphorylation}

We, and others, have previously shown the importance of IRS-mediated signal transduction pathways (especially that via IRS-2) contributing to control of $\beta$-cell proliferation (Withers et al. 1997, 1999, Hügl et al. 1998, Schuppin et al. 1998). As such, it was examined whether PMA modulated glucose/IGF-I-induced IRS signaling in INS-1 cells. Treatment of quiescent INS-1 cells for $10 \mathrm{~min}$ with $15 \mathrm{mM}$ glucose alone resulted in increased Erk1/2 phosphorylation activation; however, glucose $(15 \mathrm{mM})$ did not independently increase PKB phosphorylation activation (Fig. 4A), in agreement with previous observations (Dickson et al. 2001, Lingohr et al. 2002b). Notwithstanding, the addition of IGF-I $(10 \mathrm{nM})$ promoted PKB phosphorylation both at $\operatorname{Ser}^{473}$ and $\mathrm{Thr}^{308}$ residues, and further increased Erkl/2 phosphorylation (Fig. 4A). In the presence of PMA, IGF-I-induced phosphorylation of $\mathrm{PKB}$ on both $\mathrm{Ser}^{473}$ and $\mathrm{Thr}^{308}$ residues was significantly reduced by $\geq 75 \%(P \leq 0 \cdot 05$; Fig. $4 \mathrm{~A})$. In contrast, the phosphorylation activation of Erk1/2 was markedly enhanced in the presence of PMA in a glucose-independent manner (approximately eightfold at 0.5 or basal $3 \mathrm{mM}$ glucose; $P \leq 0.001$; Fig 4A), and further increased $15 \mathrm{mM}$ glucose/IGF-I-induced Erk1/2 phosphorylation three- to fourfold $(P \leq 0 \cdot 005$; Fig. 4A). Phosphorylation activation of $\mathrm{p} 70^{\mathrm{S} 6 \mathrm{~K}}$ in INS-1 cells was promoted by $15 \mathrm{mM}$ glucose and IGF-I over a 30-min period, resulting in an increased mobility shift in polyacrylamide gel electrophoresis (Fig. 4B), as previously recognized (Dickson et al. 2001, Lingohr et al. 2002b). In contrast to the diverse effects of PMA on Erk1/2 and PKB activation, PMA treatment of INS-1 cells did not appear to have a significant effect on glucose/IGF-I-induced p $70^{\text {S6K }}$ phosphorylation (Fig. 4B). It was also examined whether PMA had an adverse effect upstream of IGF-I-induced PKB phosphorylation at the level of IGF-I-induced IRS-2 association with the p85 regulatory subunit of PI3-K. Co-immunoprecipitation analysis showed that at a stimulatory $15 \mathrm{mM}$ glucose IGF-I induced a significant $\sim 50 \%$ increased IRS-2/p85 PI3-K interaction $(P \leq 0 \cdot 05)$, that was significantly reduced in the presence of PMA (Fig. 4G).

\section{The general PKC inhibitor Gö6850 prevented the PMA-mediated changes in PKB and Erk1/2 phosphorylation}

The bisindolylmaleimide Gö6850 is a general PKC isoform inhibitor, which has improved selectivity compared with staurosporine regarding the inhibition of protein kinases other than PKC (Toullec et al. 1991). Moreover, Gö6850 alleviated FFAinduced inhibition of IGF-I-induced PKB activation (Fig. 2), as well as reversed PMA-induced inhibition of glucose/IGF-I-induced $\beta$-cell (INS-1) mitogenesis (Fig. 3), suggesting an effect mediated by a conventional or novel PKG isoform. We examined whether these PKG isoforms were implicated in PMA-mediated inhibition of glucose/ IGF-I-induced PKB phosphorylation activation and PMA-induced activation of Erk1/2 (Fig. 5A), using a titration inhibition analysis of Gö6850 $(0-5 \mu \mathrm{M})$. The Gö6850 did not affect glucose/IGFI-induced $\mathrm{PKB}$ or Erk1/2 phosphorylation activation in the absence of PMA (Fig. 5). However, Gö6850 completely alleviated the PMA-induced inhibition of IGF-I-induced PKB phosphorylation activation $>1 \mu \mathrm{M} \quad$ Gö6850 $\quad\left(\mathrm{IC}_{50} \sim 200 \mathrm{nM}\right.$ Gö6850; Fig. 5A). Likewise, Gö6850 also inhibited the PMA-induced activation of Erk1/2 which was maximal at $>1 \mu \mathrm{M}$ Gö6850 $\left(\mathrm{IC}_{50} \sim 200 \mathrm{nM}\right.$ Gö6850; Fig. 5B). This implied that the contrasting PMA effects on PKB and Erk1/2 activation were mediated by conventional and/or novel PKC isoforms (note that PMA is not effective in activating atypical PKC isoforms (Kazanietz et al. 2000)), and not by other phorbol receptors (Ron \& Kazanietz 1999).

\section{The relative isoform-specific PKC inhibitors, Rottlerin and Gö6976, had contrasting effects on Erk1/2 and PKB phosphorylation}

In order to narrow down which particular PKC isoforms might be mediating the PMA-induced effects in $\beta$-cells, a titration inhibition analysis of PMA induced activation of Erk1/2 and alleviation 

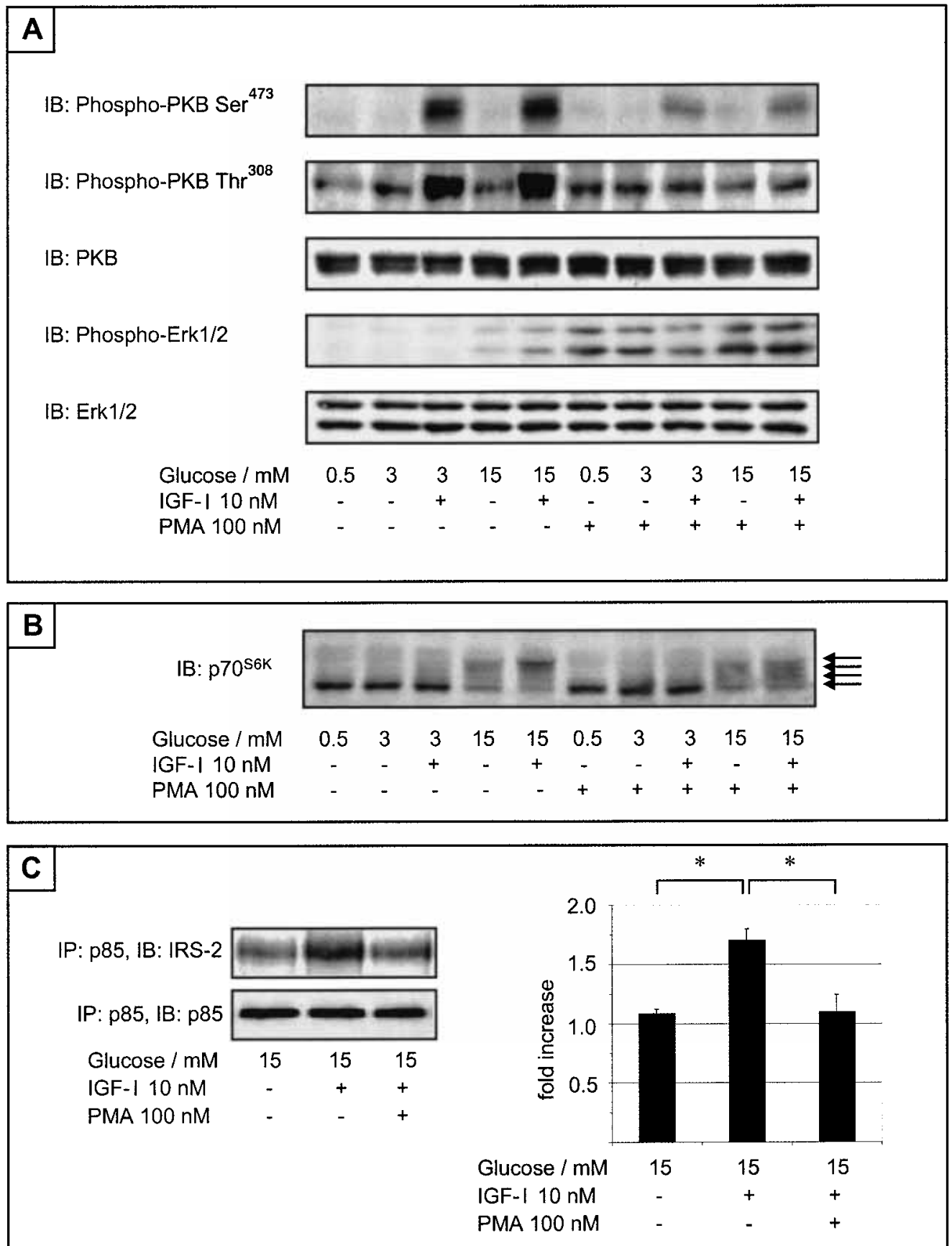

Figure 4 The effect of PMA on mitogenic signaling pathways in INS-1 cells. INS- 1 cells were made quiescent for $18 \mathrm{~h}$ then incubated for $10 \mathrm{~min}$ ( $\mathrm{A}$ and $\mathrm{C}$ ) or $30 \mathrm{~min}(\mathrm{~B})$ with the indicated glucose concentrations $\pm 10 \mathrm{nM}$ IGF-I with or without $100 \mathrm{nM}$ PMA. Cell lysates were prepared and immunoblotted (IB) with antibodies for phospho-PKB Ser ${ }^{473}$, phospho-PKB Thr ${ }^{308}$, total PKB, phospho-Erk1/2 and total Erk1/2 (A) or p70 ${ }^{\mathrm{S} 6 \mathrm{~K}}(\mathrm{~B})$, as described in Materials and methods. For the co-immunoprecipitation (IP) analysis (C), $1 \mathrm{mg}$ cell lysates were immunoprecipitated with p85 antibody and immunoblotted for $\mathrm{p} 85$ and IRS-2. A representative immunoblot of at least three individual experiments is shown $(A-C)$ and means \pm S.E. of at least three independent experiments are shown for IRS-2/p85 PI3-K co-immunoprecipitation analysis (C). ${ }^{\star} P \leq 0.05$. 


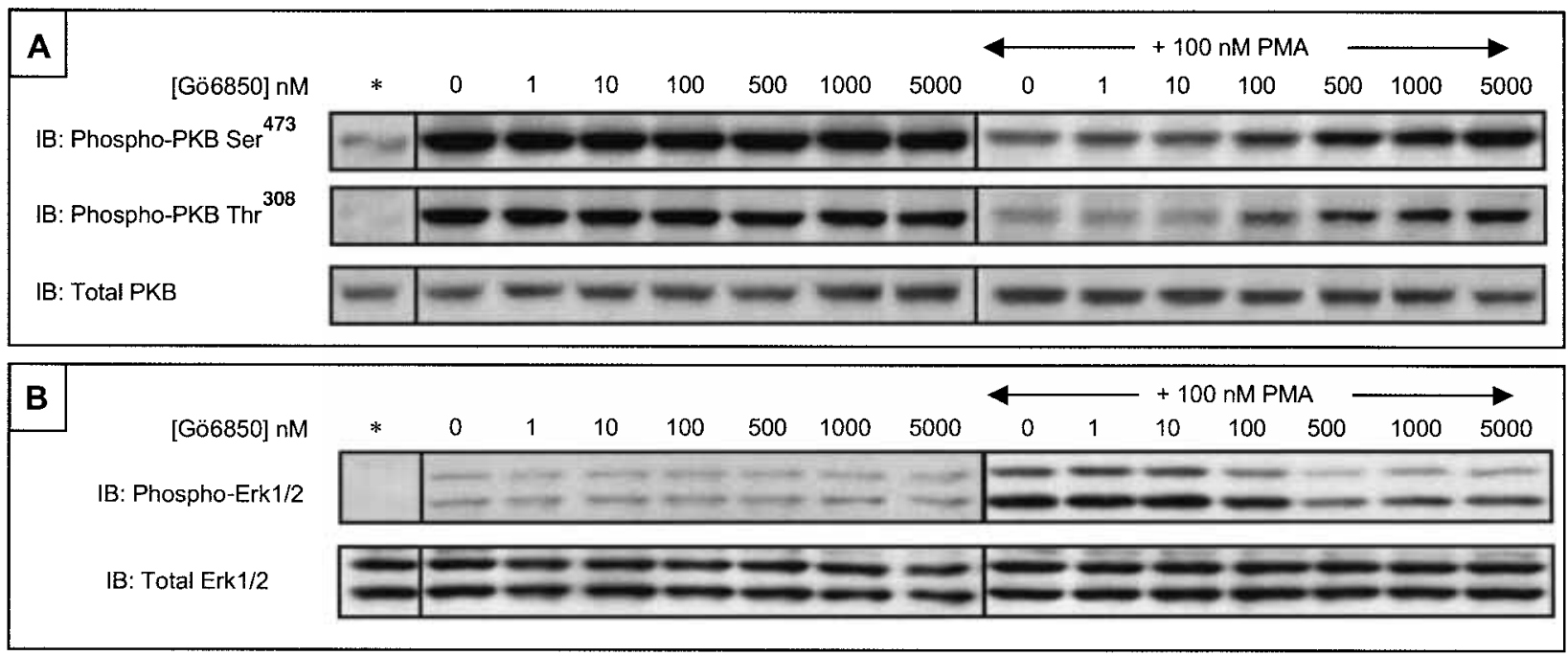

Figure 5 Immunoblot (IB) analysis of INS-1 cells treated with Gö6850. Quiescent INS-1 cells were pretreated for $2 \mathrm{~h}$ with Gö6850 $(0-5 \mu \mathrm{M})$ in media containing $0.5 \mathrm{mM}$ glucose, followed by a 10-min incubation at $15 \mathrm{mM}$ glucose $+10 \mathrm{nM}$ IGF-I with or without $100 \mathrm{nM}$ PMA. Control cells $\left(^{*}\right)$ were incubated in $0.5 \mathrm{mM}$ glucose. Cell lysates were subjected to immunoblot analysis with antibodies for phospho-PKB Ser ${ }^{473}$, phospho-PKB Thr ${ }^{308}$ and total PKB (A) or antibodies for phospho-Erk1/2 and total Erk1/2 (B), as described in Materials and methods. A representative immunoblot of at least three independent experiments is shown.

of PMA-mediated inhibition of IGF-I-induced PKB phosphorylation was examined using the relatively PKC isoform-specific inhibitors Rottlerin and Gö6976.

In cell culture experiments, Rottlerin has a lower $\mathrm{IC}_{50}$ for the novel PKC- $\delta$ than for conventional and atypical PKG isoforms (Gschwendt et al. 1994). In this study, we found that Rottlerin dose dependently inhibited glucose/IGF-I-induced Erk1/2 phosphorylation in the absence or presence of PMA, although the effect was greater in the presence of PMA (Fig. 6B). The calculated $\mathrm{IC}_{50}$ for Rottlerin-mediated inhibition of PMA-induced Erk1/2 phosphorylation was $3 \cdot 7 \pm 0 \cdot 4 \mu \mathrm{M} \quad(n=4)$ and that for glucose/IGF-I-induced Erkl/2 phosphorylation in the absence of PMA was $4 \cdot 3 \pm 0 \cdot 3 \mu \mathrm{M} \quad(n=4)$ equivalent to that for the Rottlerin $\mathrm{IC}_{50}$ to inhibit PKC- $\delta$ activity between 3 and $5 \mu \mathrm{M}$ in intact cells (Gschwendt et al. 1994). These data might be suggestive of a PMA-induced phosphorylation activation of Erk1/2 in INS- 1 cells mediated by $\mathrm{PKC}-\delta$. In contrast to effects on Erk1/2, Rottlerin failed to alleviate the PMAmediated inhibition of IGF-I-induced PKB phosphorylation in INS-1 cells (Fig. 6A), suggesting that it was unlikely that the PMA-mediated inhibition of
IGF-I-induced PKB phosphorylation in $\beta$-cells was via $\mathrm{PKC}-\delta$. However, a proviso should be made over the interpretation that the effects of Rottlerin are all attributable to $\mathrm{PKC}-\delta$ inhibition. Rottlerin may not directly inhibit PKG- $\delta$ (Davies et al. 2000, Soltoff 2001) and is capable of inhibiting a few other lipid-activated protein kinase activities (Davies et al. 2000). In this latter regard, it was noted that Rottlerin inhibited IGF-I-induced PKB phosphorylation in INS-1 cells (Fig. 6A), albeit at a significantly higher concentration $\left(\mathrm{IC}_{50}\right.$ of $9 \cdot 4 \pm 0 \cdot 6 \mu \mathrm{M}(n=3) ; P<0 \cdot 05)$ than that required to inhibit PKC- $\delta$ activity in $\beta$-cells $\left(\mathrm{IC}_{50}\right.$ between 3 and $5 \mu \mathrm{M}$ (Gschwendt et al. 1994)), or PMAinduced phosphorylation of Erk1/2 (Fig. 6B). It has previously been reported that Rottlerin can also inhibit PDK-1 activity in vitro (Davies et al. 2000) and, in an in vitro assay as previously described (Dickson et al. 2001), using recombinant PDK-1, we also found that Rottlerin inhibited PDK-1 activity with an $\mathrm{IG}_{50}$ between 9 and $11 \mu \mathrm{M}$ (data not shown). This would be consistent with the observed Rottlerin-mediated inhibition of IGF-I-induced PKB-Thr ${ }^{308}$ phosphorylation (Fig. 2), which is catalyzed by PDK-1 (Dickson et al. 2001). Notwithstanding, due to the questionable specificity 


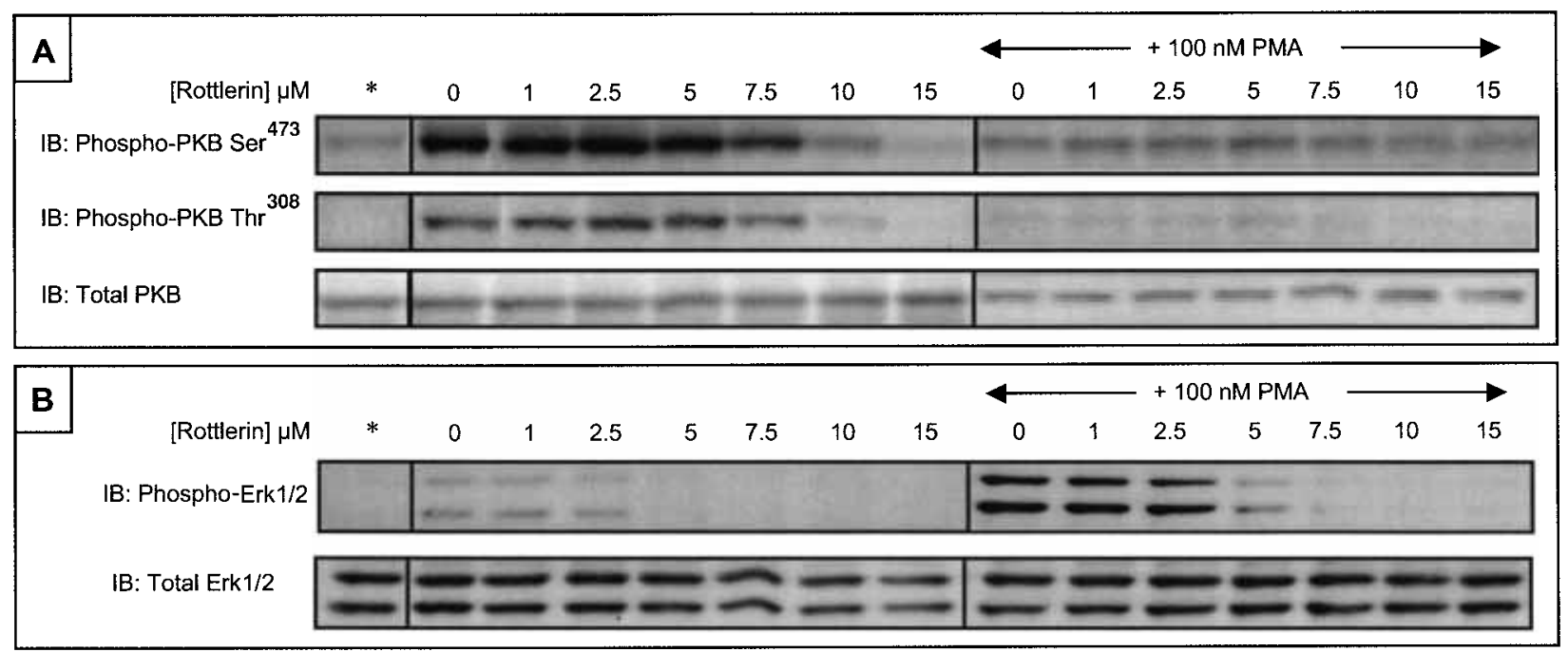

Figure 6 The effect of the novel PKC inhibitor Rottlerin on PKB and Erk1/2 phosphorylation in INS-1 cells. Quiescent INS-1 cells were preincubated for 20 min with the indicated concentrations of Rottlerin $(0-15 \mu \mathrm{M})$ in media containing $0.5 \mathrm{mM}$ glucose, followed by a 10-min incubation at $15 \mathrm{mM}$ glucose $+10 \mathrm{nM}$ IGF-I with or without $100 \mathrm{nM}$ PMA. Control cells (*) were incubated in $0.5 \mathrm{mM}$ glucose. Cell lysates were subjected to immunoblot (IB) analysis with antibodies for phospho-PKB Ser ${ }^{473}$, phospho-PKB Thr ${ }^{308}$ and total PKB (A) or antibodies for phospho-Erk1/2 and total Erk1/2 (B), as described in Materials and methods. A representative immunoblot of at least three independent experiments is shown.

of Rottlerin for PKC- $\delta$ (Davies et al. 2000, Soltoff 2001), it would be premature to conclusively state that PKC- $\delta$ mediates PMA-induced Erk1/2 phosphorylation, and although this remains a possibility other experiments are required to substantiate this notion.

The PKC inhibitor Gö6976, an indolocarbazole derivative, selectively inhibits the conventional PKC isoforms $\alpha$ and $\beta$ (Martiny-Baron et al. 1993). The Gö6976 had no effect on IGF-I-induced PKB at $\operatorname{Ser}^{473}$ or $\mathrm{Thr}^{308}$ phosphorylation in the absence of PMA, neither did it alleviate PMA-mediated inhibition of IGF-I-induced PKB phosphorylation (Fig. 7A). This indicated that conventional PKC isoforms are not necessarily involved in PMAinduced inhibition of IGF-I-induced PKB phosphorylation activation in $\beta$-cells. The Gö6976 also appeared to have no effect on independent PMA-induced phosphorylation of Erk1/2 (Fig. 7B), indicating that it is not conventional $\mathrm{PKC}$ isoforms that mediate PMA-induced Erkl/2 phosphorylation in $\beta$-cells. However, glucose/IGF-I-induced Erk1/2 phosphorylation, in the presence or absence of PMA, was enhanced by approximately fivefold at $>1 \mu \mathrm{M}$ Gö6976 (half maximal activation $=93 \pm 12 \mathrm{nM}$ Gö6976 $(n=3)$; Fig. 7B). This suggested a possible inhibitory effect of conventional PKG isoforms on glucose/IGF-Iinduced Erkl/2 activation.

\section{Discussion}

Several signaling molecules involved in mitogenic pathways, especially certain lipid moieties (Bell \& Burns 1991, Nishizuka 1992), have been described to activate $\mathrm{PKC}$ isoforms that may have a possible role in $\beta$-cell mitogenesis and/or survival (Lingohr et al. 2002a). However, such signaling molecules can differentially activate different PKC isoforms (Bell \& Burns 1991, Nishizuka 1992, Liu 1996). Thus, a comparison of the effects of the potentially relevant PKC activators in the $\beta$-cell, PIP3, oleate, palmitate, oleoyl-CoA and palmitoyl-CoA with the known allosteric activators, PS, DAG and $\mathrm{Ca}^{2+}$, was investigated in an in vitro assay. As anticipated, the conventional PKCs (PKC- $\alpha$ and $-\beta 1$ ) were most effectively activated by the combination of $\mathrm{Ca}^{2+}$, DAG and PS, the novel PKC- $\delta$ was best activated by DAG and PS in the absence of $\mathrm{Ca}^{2+}$, and atypical $\mathrm{PKC}-\zeta$ activity was increased by PIP3 as previously described (Bell \& Burns 1991, Nishizuka 1992, Toker et al. 1994, Liu 1996). It was also found that the activated FFA, oleoyl-CoA and 


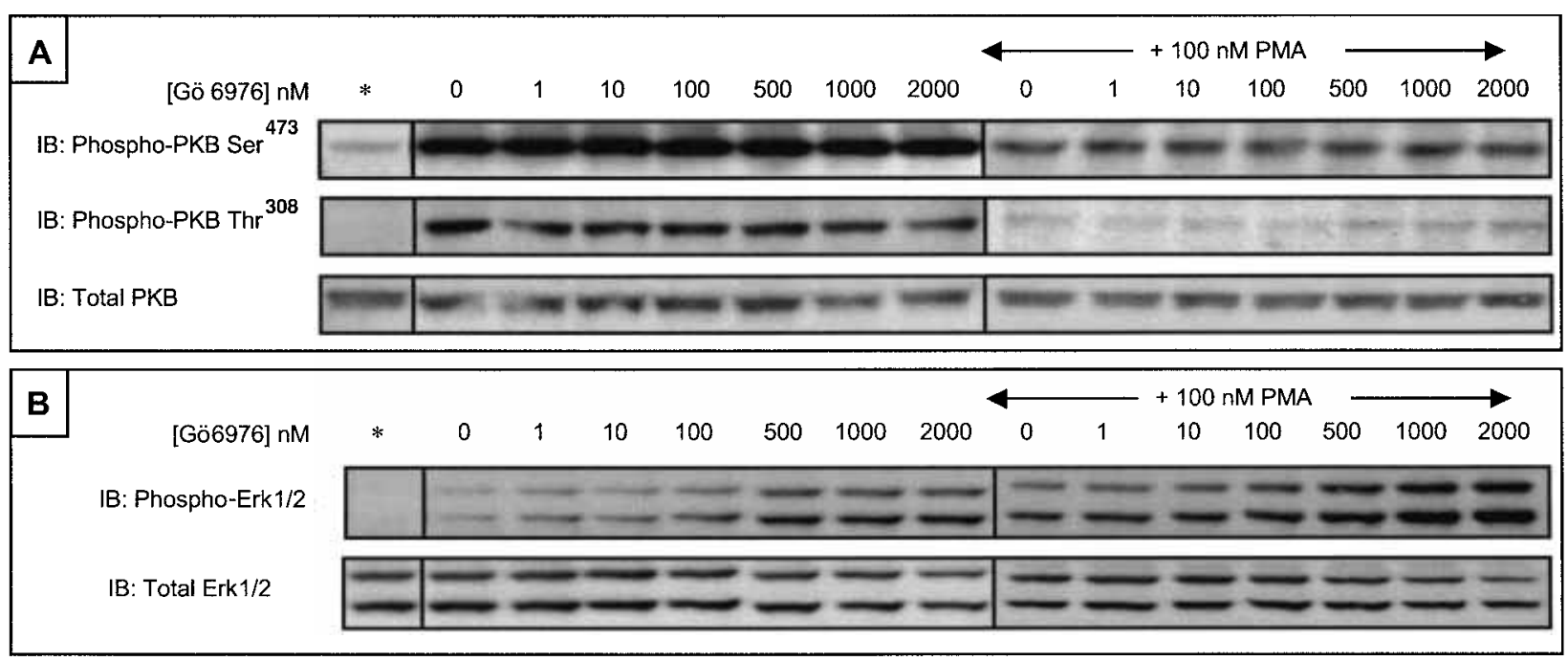

Figure 7 The effect of the conventional PKC inhibitor Gö6976 on PKB and Erk1/2 phosphorylation in INS-1 cells. Quiescent INS-1 cells were preincubated for $2 \mathrm{~h}$ with the indicated concentrations of Gö6976 (0-2 $\mu \mathrm{M})$ in media containing $0.5 \mathrm{mM}$ glucose, followed by a 10-min incubation at $15 \mathrm{mM}$ glucose $+10 \mathrm{nM}$ IGF-I with or without $100 \mathrm{nM}$ PMA. Control cells $\left(^{*}\right)$ were incubated in $0.5 \mathrm{mM}$ glucose. Cell lysates were subjected to immunoblot (IB) analysis with antibodies for phospho-PKB Ser ${ }^{473}$, phospho-PKB Thr ${ }^{308}$ and total PKB (A) or antibodies for phospho-Erk1/2 and total Erk1/2 (B), as described in Materials and methods. A representative immunoblot of at least three independent experiments is shown.

palmitoyl-CoA, but not unesterified FFA, independently increased the activity of all PKC isoforms examined in vitro, particularly that of the novel PKC- $\delta$ (Fig. 1G). As such, it can be envisaged that accumulation of long-chain acyl-CoA, but not unesterified FFA, can result in increased PKC activity in $\beta$-cells and particularly novel PKC isoform activation. In addition to FFA-CoA activation, all $\mathrm{PKC}$ isoforms, but predominantly $\mathrm{PKC}-\delta$ and $\mathrm{PKC}-\zeta$, were activated by the product of PI3-K activation, PIP3. A transient PIP3induced activation of $\mathrm{PKC}-\zeta$ would be consistent for a role of PKC- $\zeta$ in glucose/GLP-1-increased $\beta$-cell mitogenesis (Buteau et al. 2001). Thus, one can envisage that certain PKC isoforms can play a positive role in influencing $\beta$-cell mitogenic signal transduction pathways. It should be noted that autophosphorylation of $\mathrm{PKC}$ isoforms was relatively modest in this in vitro assay, and that the protein kinases found downstream of PI3-K, PDK-1 and PKB, in constitutively active forms had no significant effect on PKG activation (data not shown). This emphasized the importance of lipid-mediated allosteric activation of $\mathrm{PKC}$ isoforms (Bell \& Burns 1991, Nishizuka 1992, Liu
1996), although it is realized that in vitro observations do not always translate into the in vivo context so that phosphorylation of certain PKC isoforms should not be fully ruled out as an additional regulator of $\mathrm{PKC}$ activity in vivo (Le Good et al. 1998).

FFA, which are chronically elevated in the course of obesity-linked type-2 diabetes, have been proposed to play a role in the failure of $\beta$-cell mass to increase in compensation of the peripheral insulin resistance (Shimabukuro et al. 1998, Rhodes 2000, Unger \& Orci 2001, Lingohr et al. 2002a). This FFA-mediated impediment in $\beta$-cell growth likely occurs via a combination of inhibiting $\beta$-cell mitogenesis (Cousin et al. 2001) and increasing $\beta$-cell apoptosis (Shimabukuro et al. 1998, Cnop et al. 2001, Wrede et al. 2002). It has been postulated, although not extensively examined, that these adverse effects of chronic FFA on maintaining a $\beta$-cell population might, in part, be mediated via activation of certain, yet to be identified, PKC isoforms (Unger \& Orci 2001, Lingohr et al. 2002a). The observation that fatty acyl-CoA, rather than FFA, activates PKC isoforms (Fig. 1) would be consistent with this idea, considering that FFA- 
induced $\beta$-cell apoptosis and inhibition of mitogenesis is also dependent on fatty acyl-CoA formation (Cousin et al. 2001, Wrede et al. 2002). In addition, one should consider that IRS-2 signal transduction pathways, especially via $\mathrm{PI} 3-\mathrm{K} / \mathrm{PKB}$, play an important role in promoting $\beta$-cell growth and survival (Lingohr et al. 2002a, Rhodes \& White 2002). The observation that FFA-induced inhibition of PKB activation can be alleviated by the general PKC inhibitor (Gö6850) (Fig. 2) also implicated chronic FFA-mediated activation of certain PKC isoforms having a negative effect on $\beta$-cell growth/survival. Neither Rottlerin nor the conventional PKC isoform inhibitor, Gö6976, could alleviate FFA-induced inhibition of PKB activation in $\beta$-cells (Fig. 2), suggestive that this might be mediated via certain novel or atypical $\mathrm{PKC}$ isoforms.

However, we have previously demonstrated that the atypical $\mathrm{PKC}-\zeta$ is involved in upregulating $\beta$-cell mitogenesis (Buteau et al. 2001). To restrict an evaluation of whether there were adverse effects of conventional or novel PKG isoform activation on pancreatic $\beta$-cell proliferation, we examined whether the phorbol ester, PMA, affected glucose/ IGF-I-induced $\beta$-cell proliferation. Phorbol esters activate conventional or novel, but not atypical, PKC isoforms (Ron \& Kazanietz 1999, Kazanietz et al. 2000). We found that PMA caused a significant reduction in glucose/IGF-I-induced $\beta$-cell mitogenesis, which was reversed in the presence of the general $\mathrm{PKC}$ isoform inhibitor, Gö6850 (Fig. 3), but not Rottlerin or the conventional PKC isoform inhibitor, Gö6976. It might be considered that $4 \mathrm{~h}$ of treatment with PMA, as used in this study, could conceivably lead to some downregulation of certain PKG isoforms (Ways et al. 1991, Ozawa et al. 1993, Yaney et al. 2002), which in turn contributed to the apparent inhibition of $\beta$-cell mitogenesis. However, in $\beta$-cells only conventional $\mathrm{PKC}$ isoforms are rapidly downregulated within a 4-h period of PMA exposure (Yaney et al. 2002). Moreover, since the inhibitory effect of PMA on $\beta$-cell mitogenesis was reversed by Gö6850, it was unlikely due to a PMA-induced downregulation of a PKC isoform. This reversibility by Gö6850 also indicated that the PMA inhibitory effect was not due to non-specific cytotoxic effects or the activation of other phorbol ester binding proteins (Kazanietz et al. 2000). Together, these observations tended to suggest that it was most likely a novel PKC isoform activity that had a negative effect on glucose/IGF-I-induced $\beta$-cell mitogenesis, but this needs to be substantiated.

IRS-2 signal transduction is important for $\beta$-cell growth and survival (Lingohr et al. 2002a, Rhodes \& White 2002). As such, the influence of PMA-activated PKG isoforms on glucose/IGF-Iinduced IRS-2-mediated signaling in INS-1 cells was investigated, using a pharmacological approach that might also better indicate which particular $\mathrm{PKC}$ isoforms could mediate the negative effect on $\beta$-cell growth. In the presence of PMA, IGF-I-induced association of IRS-2 with the p85 regulatory subunit of PI3-K, which results in PI3-K activation (Benito et al. 1996, Rhodes \& White 2002), was significantly inhibited in $\beta$-cells correlating with PMA-induced inhibition of $\beta$-cell mitogenesis. This, in turn, brought about a PMA-induced inhibition of PKB phosphorylation activation, which is downstream of IRS-2 and PI3-K in the signal transduction cascade (Benito et al. 1996, Dickson et al. 2001). The PMA-induced inhibition of IGF-I-induced PKB phosphorylation was reversed by the general PKG inhibitor, Gö6850, but not by Rottlerin or the conventional PKC isoform inhibitor, Gö6976, similarly to FFA-induced inhibition of PKB phosphorylation activation (Fig. 2). Since phorbol esters are not particularly effective at activating atypical PKC isoforms (Liu 1996, Kazanietz et al. 2000), our data are consistent with the notion that a novel PKC isoform was involved in FFA/PMA-induced inhibition of $\mathrm{PKB}$ activation, As Rottlerin has been considered a PKC- $\delta$ inhibitor (Gschwendt et al. 1994), and was not particularly effective in rescuing FFA/PMA-induced inhibition of PKB phosphorylation activation, it might be suggested that alternative novel PKC isoforms to $\mathrm{PKC}-\delta$ contributed to FFA/PMA-induced inhibition of $\beta$-cell growth. However, such a conclusion is only tentative since Rottlerin is capable of inhibiting other protein kinases (Davies et al. 2000), and not very effective at inhibiting $\mathrm{PKC}-\delta$ in vitro (Davies et al. 2000, Soltoff 2001). As such, alternative, more specific experimental approaches are required to pin-point which particular novel $\mathrm{PKG}$ isoform can contribute to FFA/PMA-induced inhibition of PKB activation. Despite a marked PMA-induced inhibition of PKB phosphorylation activation, PMA did not appear to affect downstream phosphorylation of $\mathrm{p} 70^{\mathrm{S} 6 \mathrm{~K}}$. However, it has 
previously been shown that glucose can activate p70 ${ }^{\text {S6K }}$ directly via mammalian target of rapamycin (mTOR), bypassing a requirement for upstream PKB activation (Dickson et al. 2001). As such, it appears that alternative PKB targets, other than $\mathrm{mTOR} / \mathrm{p} 70^{\mathrm{S} 6 \mathrm{~K}}$, are more pertinent to glucose/ IGF-I-mediated control of $\beta$-cell mitogenesis.

In contrast to PMA inhibitory effects on PKB activation, a PMA-induced Erk1/2 phosphorylation activation was observed, independent of glucose and IGF-I. This perhaps provides an explanation as to why PMA-induced inhibition of $\beta$-cell mitogenesis was only partial, since glucose/ IGF-I-induced Erk1/2 activation has previously been indicated to contribute to $\beta$-cell mitogenesis in addition to the PI3-K signaling pathway (Hügl et al. 1998, Dickson et al. 2001). The PMA-induced Erk1/2 phosphorylation was inhibited by the general PKG inhibitor, Gö6850, suggesting that it was mediated by a PKC isoform. This is consistent with previous observations that Erkl/2 can be activated via PKC-induced phosphorylation activation of Raf-1, independent of Ras, upstream of mitogen activated protein kinase kinase (MEK) and Erk1/2 (Ueda et al. 1996, Pearson et al. 2001). Alternatively, since PMA-inhibited PKB activation, these observations might also reflect an alleviation of PKB-mediated inhibition of Erk1/2 phosphorylation activation, previously observed in $\beta$-cells (Dickson et al. 2001). However, the preferential conventional PKG isoform inhibitor, Gö6976, further increased glucose/IGF-I- and PMAinduced Erk1/2 phosphorylation in a dosedependent manner without affecting PKB activation, suggesting that conventional $\mathrm{PKC}$ isoforms can negatively affect Erk $1 / 2$ activation independent of PKB. It has been previously shown in other cell types that PMA-mediated Erk1/2 activation was reduced when constitutively active conventional PKCs $(\alpha$ and $\beta 1$ ) were expressed, whereas expression of novel and atypical PKGs $(\delta, \varepsilon$ and $\zeta)$ potentiated PMA-mediated Erk1/2 activation (Ueda et al. 1996, Schönwasser et al. 1998). Titration inhibition of PMA-induced Erk1/2 phosphorylation by Rottlerin suggested that it might be mediated by PKC- $\delta$ in $\beta$-cells, as found in other cell types (Ueda et al. 1996, Pearson et al. 2001). However, given the reservation about Rottlerin's specificity and ability to directly inhibit PKC- $\delta$ (Davies et al. 2000, Soltoff 2001), this would be a premature and tentative conclusion. While
PKC- $\delta$-mediated phosphorylation activation of the Rafl/Mek/Erk1/2 pathway in $\beta$-cells remains a possibility, further experimentation is required to better demonstrate this. Notwithstanding, it should be noted that Erk1/2 activation in $\beta$-cells is complex and, as well as activation by a novel PKC isoform, it can be influenced by elevation in $\mathrm{Ca}^{2+}$ and/or cAMP via increased glucose metabolism (Frodin et al. 1995, Khoo \& Cobb 1997, Benes et al. 1999) as well as via tyrosine phosphorylation of IRS-2 and Shc (Hügl et al. 1998). In this latter regard, it is interesting to note that despite PMA-mediated inhibition of IGF-I-induced IRS-2/ p85-PI3-K association, a PMA-induced increased Erk1/2 phosphorylation activation was still observed. This indicates the importance of alternative signaling pathways in the $\beta$-cell, independent of IRS-2 (e.g. via Shc, $\mathrm{Ca}^{2+}$ and/or cAMP), in mediating glucose/IGF-I-induced Erk1/2 phosphorylation activation.

In summary, we postulate that FFA/PMAinduced inhibition of PKB phosphorylation activation leads to a decreased glucose/IGF-I-induced $\beta$-cell mitogenesis and might be contributed via chronic activation of a novel PKC isoform. Admittedly, this supposition is mostly based on observations derived from pharmacological titration inhibition experiments, and the putative role of a novel PKC isoform in mediating FFA/PMAinduced inhibition of $\mathrm{PKB}$ phosphorylation in $\beta$-cells will have to be confirmed using a complementary molecular approach. Nonetheless, it is known that of the family of novel PKC isoforms, PKC- $\delta$, $-\varepsilon$ and $-\mu$ are expressed in $\beta$-cells (Yaney et al. 2002), and this initial characterization study has narrowed the field to these candidate novel PKG isoforms to interfere with IRS-2mediated mitogenic signal transduction pathways in $\beta$-cells. Intriguingly, FFA-induced activation of novel PKC isoforms in skeletal muscle have been shown to play a negative role on insulin signal transduction pathways contributing to the pathogenesis of insulin resistance in vivo (Griffin et al. 1999, Laybutt et al. 1999, Patti 1999, Kraegen et al. 2001, Moller 2001). If, in future studies, it becomes apparent that the same novel PKG isoforms which cause peripheral insulin resistance also have a negative effect on $\beta$-cell growth, then one might envisage these as novel pharmacological targets that could both alleviate insulin resistance and preserve compensating increases in $\beta$-cell mass to 
slow the pathogenic course of obesity-linked type-2 diabetes.

\section{Acknowledgements}

This work was supported by the National Institutes of Health DK 55267 (G J R) and by the Juvenile Diabetes Foundation International ( $\mathrm{G} J \mathrm{R})$. We thank Cynthia Jacobs for the preparation of this manuscript.

\section{References}

Asfari M, Janjic D, Meda P, Guodong L, Halban PA \& Wollheim CB 1992 Establishment of 2-mercaptoethanol-dependent differentiated insulin-secreting cell lines. Endocrinology 130 167-178.

Bell RM \& Burns DJ 1991 Lipid activation of protein kinase-C. Fournal of Biological Chemistry 266 4661-4664.

Benes C, Poitout V, Marie JC, Martin-Perez J, Roisin MP \& Fagard R 1999 Mode of regulation of the extracellular signal-regulated kinases in the pancreatic beta-cell line MIN6 and their implication in the regulation of insulin gene transcription. Biochemical fournal 340 219-225.

Benito M, Valverde AM \& Lorenzo M 1996 IGF-I: a mitogen also involved in differentiation processes in mammalian cells. International Fournal of Biochemistry and Cell Biology 28 499-510.

Bollheimer LC, Skelly RH, Chester M, McGarry JD \& Rhodes CJ 1998 Chronic exposure to free fatty acid reduces pancreatic $\beta$-cell insulin content by increasing basal insulin secretion that is not compensated for a corresponding increase in proinsulin biosynthesis translation. Fournal of Clinical Investigation $\mathbf{1 0 1}$ 1094-1101.

Bronfman M, Morales MN \& Orellana A 1988 Diacylglycerol activation of protein kinase $\mathrm{C}$ is modulated by long-chain acyl-CoA. Biochemical and Biophysical Research Communications 152 987-992.

Buteau J, Foisy S, Rhodes CJ, Carpenter L, Biden TJ \& Prentki M 2001 Protein kinase Czeta activation mediates glucagon-like peptide-1- induced pancreatic beta-cell proliferation. Diabetes $\mathbf{5 0}$ 2237-2243.

Chakravarthy B, Morley P \& Whitfield J $1999 \mathrm{Ca}^{2+}$-calmodulin and protein kinase Cs: a hypothetical synthesis of their conflicting convergences on shared substrate domains. Trends in Neurosciences 22 12-16.

Chen SG \& Murakami K 1992 Synergistic activation of type III protein kinase $\mathrm{C}$ by cis-fatty acid and diacylglycerol. Biochemical Fournal 282 33-39.

Cnop M, Hannaert JC, Hoorens A, Eizirik DL \& Pipeleers DG 2001 Inverse relationship between cytotoxicity of free fatty acids in pancreatic islet cells and cellular triglyceride accumulation. Diabetes 50 1771-1777.

Cousin SP, Hügl SR, Wrede CE, Kajio H, Myers MG Jr \& Rhodes CJ 2001 Free fatty acid-induced inhibition of glucose and insulin-like growth factor I-induced deoxyribonucleic acid synthesis in the pancreatic beta-cell line INS-1. Endocrinology 142 229-240.

Davies SP, Reddy H, Caivano M \& Cohen P 2000 Specificity and mechanism of action of some commonly used protein kinase inhibitors. Biochemical fournal 351 95-105.
De Fea K \& Roth RA 1997 Protein kinase C modulation of insulin receptor substrate-1 tyrosine phosphorylation requires serine 612 . Biochemistry 36 12939-12947.

Dickson LM, Lingohr MK, McCuaig J, Hugl SR, Snow L, Kahn BB, Myers MG Jr \& Rhodes CJ 2001 Differential activation of protein kinase $\mathrm{B}$ and $\mathrm{p} 70(\mathrm{~S} 6) \mathrm{K}$ by glucose and insulin-like growth factor 1 in pancreatic beta-cells (INS-1). Fournal of Biological Chemistry 276 21110-21120.

Fall CH 2001 Non-industrialised countries and affluence. British Medical Bulletin $6033-50$.

Frodin M, Sekine N, Roche E, Filloux C, Prentki M, Wollheim CB \& Van Obberghen E 1995 Glucose, other secretagogues, and nerve growth factor stimulate mitogen-activated protein kinase in the insulin-secreting beta-cell line, INS-1. Fournal of Biological Chemistry $2707882-7889$.

Griffin ME, Marcucci MJ, Cline GW, Bell K, Barucci N, Lee D, Goodyear LJ, Kraegen EW, White MF \& Shulman GI 1999 Free fatty acid-induced insulin resistance is associated with activation of protein kinase $\mathrm{C}$ theta and alterations in the insulin signaling cascade. Diabetes 48 1270-1274.

Gschwendt M, Muller HJ, Kielbassa K, Zang R, Kittstein W, Rincke G \& Marks F 1994 Rottlerin, a novel protein kinase inhibitor. Biochemical and Biophysical Research Communications 199 93-98.

Hügl SR, White MF \& Rhodes CJ 1998 IGF-1 stimulated pancreatic $\beta$-cell growth is glucose dependent: synergistic activation of IRS-mediated signal transduction pathways by glucose and IGF-1 in INS-1 cells. Fournal of Biological Chemistry 273 17771-17779.

Kazanietz MG, Caloca MJ, Eroles P, Fujii T, Garcia-Bermejo ML, Reilly M \& Wang H 2000 Pharmacology of the receptors for the phorbol ester tumor promoters: multiple receptors with different biochemical properties. Biochemical Pharmacology 60 1417-1424.

Kellerer M \& Haring HU 1995 Pathogenesis of insulin resistance: modulation of the insulin signal at receptor level. Diabetes Research and Clinical Practice 28 (Suppl) S173-7.

Khoo S \& Cobb MH 1997 Activation of mitogen-activating protein kinase by glucose is not required for insulin secretion. PNAS 94 5599-5604.

Knutson KL \& Hoenig M 1994 Identification and subcellular characterization of protein kinase-C isoforms in insulinoma beta-cells and whole islets. Endocrinology 135 881-886.

Kraegen EW, Cooney GJ, Ye JM, Thompson AL \& Furler SM 2001 The role of lipids in the pathogenesis of muscle insulin resistance and beta cell failure in type II diabetes and obesity. Experimental and Clinical Endocrinology and Diabetes 109 (Suppl 2) S189-S201.

Laybutt DR, Schmitz-Peiffer C, Saha AK, Ruderman NB, Biden TJ \& Kraegen EW 1999 Muscle lipid accumulation and protein kinase $\mathrm{C}$ activation in the insulin-resistant chronically glucoseinfused rat. American Fournal of Physiology 277 E1070-E1076.

Le Good JA, Ziegler WH, Parekh DB, Alessi DR, Cohen P \& Parker PJ 1998 Protein kinase C isotypes controlled by phosphoinositide 3-kinase through the protein kinase PDK1. Science $2812042-2045$.

Lingohr MK, Buettner R \& Rhodes CJ 2002a Pancreatic beta-cell growth and survival - a role in obesity-linked type 2 diabetes? Trends in Molecular Medicine 8 375-384.

Lingohr MK, Dickson LM, McCuaig JF, Hügl SR, Twardzik DR $\&$ Rhodes CJ 2002b Activation of IRS-2 mediated signal transduction by IGF-1, but not TGF- $\alpha$ or EGF, augments pancreatic $\beta$-cell proliferation. Diabetes 51 966-976.

Liu J-P 1996 Protein kinase C and its substrates. Molecular and Cellular Endocrinology 116 1-29.

McGarry JD \& Dobbins RL 1999 Fatty acids, lipotoxicity and insulin secretion. Diabetologia 42 128-138.

Martiny-Baron G, Kazanietz MG, Mischak H, Blumberg PM, Kochs G, Hug H, Marme D \& Schachtele C 1993 Selective 
inhibition of protein kinase $\mathrm{C}$ isozymes by the indolocarbazole Gö6976. Fournal of Biological Chemistry $2689194-9197$.

Mokdad AH, Bowman BA, Ford ES, Vinicor F, Marks JS \& Koplan JP 2001 The continuing epidemics of obesity and diabetes in the United States. Fournal of the American Medical Association 286 $1195-1200$.

Moller DE 2001 New drug targets for type 2 diabetes and the metabolic syndrome. Nature 414 821-827.

Mosior M \& Newton AC 1995 Mechanism of interaction of protein kinase $\mathrm{C}$ with phorbol esters. Reversibility and nature of membrane association. Fournal of Biological Chemistry $\mathbf{2 7 0}$ 25526-25533.

Murakami K \& Routtenberg A 1985 Direct activation of purified protein kinase $\mathrm{C}$ by unsaturated fatty acids (oleate and arachidonate) in the absence of phospholipids and $\mathrm{Ca}^{2+}$. FEBS Letters 192 189-193.

Nishizuka Y 1992 Intracellular signaling by hydrolysis of phospholipids and activation of protein kinase-C. Science $\mathbf{2 5 8}$ 607-613.

Ozawa K, Szallasi Z, Kazanietz MG, Blumberg PM, Mischak H, Mushinski JF \& Beaven MA $1993 \mathrm{Ca}(2+)$-dependent and $\mathrm{Ca}(2+)$-independent isozymes of protein kinase $\mathrm{C}$ mediate exocytosis in antigen-stimulated rat basophilic RBL-2H3 cells. Reconstitution of secretory responses with $\mathrm{Ca} 2+$ and purified isozymes in washed permeabilized cells. Fournal of Biological Chemistry 268 1749-1756.

Patti ME 1999 Nutrient modulation of cellular insulin action. Annals of the New York Academy of Sciences 892 187-203.

Pearson G, Robinson F, Beers Gibson T, Xu BE, Karandikar M, Berman K \& Cobb MH 2001 Mitogen-activated protein (MAP) kinase pathways: regulation and physiological functions. Endocrine Reviews 22 153-183.

Rhodes CJ 2000 Insulin-like growth factor-1 and growth hormone post receptor signaling mechanisms for pancreatic $\beta$-cell replication. Fournal of Molecular Endocrinology 24 303-311.

Rhodes CJ \& White MF 2002 Molecular insights into insulin action and secretion. European fournal of Clinical Investigation 32 (Suppl 3) $3-13$

Ron D \& Kazanietz MG 1999 New insights into the regulation of protein kinase $\mathrm{C}$ and novel phorbol ester receptors. FASEB fournal 13 1658-1676.

Schmitz-Peiffer C, Craig DL \& Biden TJ 1999 Ceramide generation is sufficient to account for the inhibition of the insulin-stimulated PKB pathway in C2C12 skeletal muscle cells pretreated with palmitate. Fournal of Biological Chemistry 274 24202-24210.

Schönwasser DG, Marais RM, Marshall GJ \& Parker PJ 1998 Activation of the mitogen-activated protein kinase/extracellular signal-regulated kinase pathway by conventional, novel, and atypical protein kinase $\mathrm{C}$ isotypes. Molecular and Cellular Biology 18 790-798.

Schuppin GT, Pons S, Hügl SR, Aiello LP, King GL, White MF \& Rhodes CJ 1998 A specific increased expression of IRS-2 in pancreatic $\beta$-cell lines is involved in mediating serum stimulated $\beta$-cell growth. Diabetes 47 1074-1084.

Shimabukuro M, Zhou YT, Levi M \& Unger RH 1998 Fatty acid-induced beta cell apoptosis: a link between obesity and diabetes. PNAS 95 2498-2502.

Soltoff SP 2001 Rottlerin is a mitochondrial uncoupler that decreases cellular ATP levels and indirectly blocks protein kinase Cdelta tyrosine phosphorylation. Fournal of Biological Chemistry 276 37986-37992.

Stein DT, Esser V, Stevenson B, Lane KE, Whiteside JH, Daniels MB, Chen S \& McGarry JD 1996 Essentiality of circulating fatty acids for glucose-stimulated insulin secretion in the fasted rat. Fournal of Clinical Investigation 97 2728-2735.

Stratford S, DeWald DB \& Summers SA 2001 Ceramide dissociates 3 '-phosphoinositide production from pleckstrin homology domain translocation. Biochemical Journal 354 359-368.

Tian YM, Urquidi V \& Ashcroft SJ 1996 Protein kinase C in beta-cells: expression of multiple isoforms and involvement in cholinergic stimulation of insulin secretion. Molecular and Cellular Endocrinology 119 185-193.

Toker A, Meyer M, Reddy KK, Falck JR, Aneja R, Aneja S, Parra A, Burns DJ, Ballas LM \& Cantley LC 1994 Activation of protein kinase $\mathrm{C}$ family members by the novel polyphosphoinositides PtdIns-3,4-P2 and PtdIns-3,4,5-P3. Fournal of Biological Chemistry $26932358-32367$

Toullec D, Pianetti PH, Coste H, Bellevergue P, Grand-Perret T, Ajakane M, Baudet V, Boissin P, Boursier E \& Loriolle F 1991 The bisindolylmaleimide GF 109203X is a potent and selective inhibitor of protein kinase C. Fournal of Biological Chemistry 266 15771-15781.

Ueda Y, Hirai S, Osada S, Suzuki A, Mizuno K \& Ohno S 1996 Protein kinase $\mathrm{C}$ activates the MEK-ERK pathway in a manner independent of Ras and dependent on Raf. Fournal of Biological Chemistry $27123512-23519$.

Unger RH \& Orci L 2001 Diseases of liporegulation: new perspective on obesity and related disorders. FASEB fournal $\mathbf{1 5}$ 312-321.

Warnotte C, Gilon P, Nenquin M \& Henquin JC 1994 Mechanisms of the stimulation of insulin release by saturated fatty acids. A study of palmitate effects in mouse beta-cells. Diabetes 43 703-711.

Ways K, Riddle R, Ways M \& Cook P 1991 Effect of phorbol esters on cytosolic protein kinase $\mathrm{C}$ content and activity in the human monoblastoid U937 cell. Fournal of Biological Chemistry 266 $1258-1264$

Withers DJ, Gutierres JS, Towery H, Ren J-M, Burks DJ, Previs S, Zhang Y, Bernal D, Pons S, Shulman GI, Bonner-Weir S \& White MF 1997 Disruption of IRS-2 causes type-2 diabetes in mice. Nature 391 900-904.

Withers DJ, Burks DJ, Towery HH, Altamuro SL, Flint CL \& White MF 1999 Irs-2 coordinates IgF-1 receptor-mediated beta-cell development and peripheral insulin signalling. Nature Genetics 23 $32-40$.

Wrede CE, Dickson LM, Lingohr MK, Briaud I, McCuaig JF \& Rhodes CJ 2002 Protein kinase B/AKt prevents fatty acid-induced apoptosis in pancreatic beta-cells (INS-1). Fournal of Biological Chemistry 277 49676-49684.

Yaney GC, Korchak HM \& Corkey BE 2000 Long-chain acyl CoA regulation of protein kinase $\mathrm{C}$ and fatty acid potentiation of glucose-stimulated insulin secretion in clonal beta-cells. Endocrinology 141 1989-1998.

Yaney GC, Fairbanks JM, Deeney JT, Korchak HM, Tornheim K \& Corkey BE 2002 Potentiation of insulin secretion by phorbol esters is mediated by $\mathrm{PKC}$-alpha and $\mathrm{nPKC}$ isoforms. American Fournal of Physiology 283 E880-E888.

Zick Y 2001 Insulin resistance: a phosphorylation-based uncoupling of insulin signaling. Trends in Cell Biology 11 437-441.

Zimmet P, Alberti KG \& Shaw J 2001 Global and societal implications of the diabetes epidemic. Nature $414782-787$.

Received in final form 3 March 2003 Accepted 13 March 2003 